\title{
Morphological Characterisation of Haemocytes in the Mealworm Beetle Tenebrio molitor (Coleoptera, Tenebrionidae)
}

\author{
Maria Luigia Vommaro ${ }^{1}$, Joachim Kurtz $^{2}$ and Anita Giglio ${ }^{1, *(1)}$ \\ 1 Department of Biology, Ecology and Earth Science, University of Calabria, 87036 Rende, Italy; \\ marialuigia.vommaro@unical.it \\ 2 Institute for Evolution and Biodiversity, University of Münster, 48149 Münster, Germany; \\ joachim.kurtz@uni-muenster.de \\ * Correspondence: anita.giglio@unical.it; Tel.: +39-098-449-2982; Fax: +39-098-449-2986
}

Citation: Vommaro, M.L.; Kurtz, J.; Giglio, A. Morphological

Characterisation of Haemocytes in the Mealworm Beetle Tenebrio molitor (Coleoptera, Tenebrionidae). Insects 2021, 12, 423. https://doi.org/ 10.3390/insects12050423

Academic Editors: Roberto Romani and Andrea Di Giulio

Received: 15 April 2021

Accepted: 6 May 2021

Published: 8 May 2021

Publisher's Note: MDPI stays neutral with regard to jurisdictional claims in published maps and institutional affiliations.

Copyright: () 2021 by the authors. Licensee MDPI, Basel, Switzerland. This article is an open access article distributed under the terms and conditions of the Creative Commons Attribution (CC BY) license (https:// creativecommons.org/licenses/by/ $4.0 /)$.
Simple Summary: Tenebrio molitor is a pest of stored grain, causing considerable damage. However, its easy maintenance makes this species also interesting as a food source and as a model for physiological, immunological, ecological and evolutionary studies. We used light and transmission electron microscopy to study the morphology of circulating haemocytes. Prohaemocytes, plasmatocytes, granular cells and oenocytoids were described based on their morphological features and staining affinity. Results are a baseline for further study aimed to clarify the structure and function of haemocytes in insects.

Abstract: The immunocompetence of the mealworm beetle Tenebrio molitor has been well investigated at molecular and physiological levels, but information on morphological and functional characteristics of its immune cells (haemocytes) is still scarce and fragmentary. This study provides an updated overview of the morphology of circulating immune cells from mealworm beetle adults, using light and transmission electron microscopy. Based on their affinities for May-Grünwald Giemsa stain, haemocytes were defined as either eosinophilic, basophilic or neutral. Ultrastructural descriptions allowed to detect four main cell types in the haemolymph: prohaemocytes, plasmatocytes, granular cells and oenocytoids. The morphological plasticity of haemocytes and the evidence of mitotic circulating cells, intermediate cell stages, as well as autophagic activities suggest haemocyte proliferation, turnover and transdifferentiation as constantly active processes in the haemolymph. Cytochemical tests revealed differences in the distribution of carbohydrates among cell types underling the great plasticity of the immune response and the direct involvement of circulating immune cells in the resource allocation. In addition, our results provide a detailed morphological description of vesicle trafficking, macro- and microautophagy, apoptotic and necrotic processes, confirming the suitability of T. molitor haemocytes as a model for studying evolutionarily conserved cellular mechanisms.

Keywords: apoptosis; autophagy; electron microscopy; exosome; haemocyte morphology; insect immunity; mitosis; vesicular trafficking

\section{Introduction}

Insects rely on physical barriers, such as the cuticle, as well as cellular and humoral immune responses to counteract parasites and pathogens in their natural environments [1,2]. Cellular defences involve haemocytes, which play a crucial role in the pathogen clearance by phagocytosis, nodule formation, encapsulation and cytotoxic reactions [3-6]. Haemocyte types have mostly been characterised referring to their morphological, histochemical and functional features [7] or based on monoclonal antibodies and genetic markers [8]. The most common morphological types are prohemocytes, granular cells, plasmatocytes, spherule cells and oenocytoids, occurring in species belonging to diverse insect orders [5,9-13]). Humoral effectors are an efficient part of the innate immune response and include production 
of antimicrobial peptides, activation of prophenoloxidase (proPO) and production of reactive oxygen species [11,14]. These effectors cooperate in species-specific pathways activated to lead the recognition and neutralisation of pathogens [15]. In Drosophila melanogaster, phagocytic plasmatocytes, PO-containing crystal cells and lamellocytes are involved in parasite encapsulation $[4,16,17]$. In Lepidoptera, phagocytic granulocytes, capsule-forming plasmatocytes, spherule cells and PO-containing oenocytoids have been identified [4].

Insects such as Diptera, Lepidoptera and Coleoptera are largely used as alternative models to vertebrates in physiological, ecological and toxicological studies because of the absence of ethical restriction, short lifecycle and easy maintenance under laboratory conditions $[18,19]$. Due to strong structural and functional similarities in the innate immune system of insects and vertebrates [20,21], studies of insect immunity could lead to a better understanding of the evolution of innate immune systems [22]. Moreover, it represent a model to test chemicals $[15,23-25]$ and bioactive molecules, including antimicrobial peptides [26] for ecotoxicological and biomedical applications.

The mealworm beetle Tenebrio molitor Linnaeus, 1758 (Coleoptera, Tenebrionidae) is a pest of stored grain facilities. On the other hand, mealworm larvae are used as a source of proteins [27,28] and fatty acids [29] for animal husbandry [30] and human nutrition (EU Regulation 2017/983). Moreover, they are able to ingest and biodegrade plastic products [31,32]. Given the growing interest in their use as food and feed, there have been a number of reports investigating the cellular and humoral immune effectors of T. molitor in relation to the wide range of pathogens that can reduce its survival and reproductive success, as reviewed [33]. Haemocyte-mediated cellular responses to biotic challenges have been extensively studied focusing on genes encoding components of the T. molitor immune system [34-36]. To date, few studies have addressed the morphological and functional variability of haemocytes in T. molitor. A previous analysis using phase contrast microscopy has shown three different cell types named oenocytoids, plasmatocytes and cystocytes [37]. Scanning electron microscopy, performed to investigate abdominal haemopoietic tissues in adults, has displayed three main morphologically distinct types of haemocytes, i.e., prohaemocytes, granulocytes and plasmatocytes [38]. The response of haemocytes to biotic (Staphylococcus aureus) and artificial (latex beads) challenges, investigated across developmental stages, has highlighted a fourth morphological type of circulating haemocytes named oenocytoids [39].

The aim of this study is to characterise the circulating haemocytes of T. molitor based on morphological and cytochemical analyses by using light and transmission electron microscopy. We focused our attention on the ultrastructure of subcellular compartments within the different populations of circulating haemocytes to update and enhance the general knowledge of their morphological variability.

\section{Materials and Methods}

\subsection{Insects}

T. molitor specimens were obtained from a laboratory stock population maintained at the Morphofunctional Entomology Laboratory, Dept. of Biology, Ecology and Earth Science of the University of Calabria. Mealworm beetles were reared at $60 \%$ relative humidity (rh) under a natural photoperiod and room temperature $(23 \pm 2)$, with an ad libitum diet of organic wheatmeal and fruit. In this study, adults, 7-10 days after eclosion were used.

\subsection{Cytochemical Analyses and Light Microscopy (LM)}

Before haemolymph collection, beetles were anaesthetised in a cold chamber at $4{ }^{\circ} \mathrm{C}$ for three minutes. To prepare haemocytes for wet and permanent mount staining, the haemolymph ( $3 \mu \mathrm{L}$ for each specimen) was collected from beetles $(n=12)$ by using a 29 -gauge needle at the ventral level of the pro-mesothorax articulation. It was mixed with $3 \mu \mathrm{L}$ of phosphate buffer (PBS, $10 \mathrm{mM} \mathrm{pH} \mathrm{7.4;} \mathrm{Merck} \mathrm{Life} \mathrm{Science,} \mathrm{Milan,} \mathrm{Italy),} \mathrm{put}$ on a poly-L-lysine-coated slide and processed according to the cytochemical methods indicated below. Except for the in vivo Neutral Red assay, slides were mounted with Eukitt 
mounting medium (Merck Life Science, Milan, Italy) and examined under a Zeiss Primo Star microscope under immersion oil at $1000 \times$ magnification. Light microscopic images of selected areas were acquired with a Redmi note pro 9 mobile phone camera connected to the ocular at a resolution of $6000 \times 8000$ pixels.

- May-Grünwald Giemsa staining. To characterise the basic cellular morphology, adherent haemocytes were first fixed in pure May-Grünwald stain (Merck, Darmstadt, Germany) for $3 \mathrm{~min}$. Then, slides were stained with a May-Grünwald solution (1:1 in distilled water) for $5 \mathrm{~min}$, followed by a Giemsa staining (Merck) (1:20 in distilled water) for $5 \mathrm{~min}$. Slides were rapidly rinsed in the distilled water, mounted and observed as indicated before. The identification of morphological cell types was based on differences in size, morphology and staining affinity.

- Phenoloxidase (PO)-haemocyte activity. PO-positive haemocytes were detected by using the method previously described in Ling et al. [40]. Briefly, as the ethanol can irreversibly activate pro-PO into PO and fix haemocytes, $1 \mathrm{mg} / \mathrm{mL}$ of L-DOPA $(3,4-$ dihydroxy-L-phenylalanine, Sigma-Aldrich, St. Louis, MO, USA) was dissolved in 35\% ethanol and the solution added to adherent haemocytes. The slides were incubated for $60 \mathrm{~min}$, in dark condition, at room temperature. Control was run simultaneously by adding haemocytes with 35\% ethanol. Finally, slides were rinsed with distilled water, mounted and observed as indicated before.

- Periodic acid-Schiff (PAS) staining. To detect carbohydrates, haemocytes were fixed adding a solution of $2.5 \%$ glutaraldehyde and $1 \%$ paraformaldehyde in $0.1 \mathrm{M}$ phosphate buffer, pH 7.4, with $1.5 \%$ sucrose. Smears were stained with a Periodic AcidSchiff Kit according to the manufacturer's protocol (P.A.S. acc.Hotchkiss-Mc Manus kit, Diaphat, Bergamo, Italy). Positive cellular compartments containing polysaccharides or glycogen stained violet to pink.

- Neutral red assay. A stock solution of Neutral Red (Sigma-Aldrich) was prepared by dissolving $20 \mathrm{mg}$ of the powdered dye in $1 \mathrm{~mL}$ of dimethyl sulphoxide (DMSO; Merck Life Science, Milan, Italy). Slides with haemolymph were incubated for $1 \mathrm{~min}$ in a humid chamber to allow haemocyte adhesion, then $40 \mu \mathrm{L}$ of a working solution (Neutral Red $175 \mathrm{mM}$ in PBS) prepared from the stock, was added. The retention of the neutral red in acidic intracellular compartments such as lysosomes (red) was observed in vivo under LM and acquired as indicated before.

\subsection{Transmission Electron Microscopy (TEM)}

Haemocytes were fixed and embedded as previously described [41]. Briefly, the last two abdominal segments of cold anaesthetised beetles were laterally cut and sterile PBS was slowly injected pricking the neck membrane through a 29-gauge needle. The haemolymph was quickly dropped from the abdomen into a microcentrifuge tube containing fixative (2.5\% glutaraldehyde and $1 \%$ paraformaldehyde in $0.1 \mathrm{M}$ phosphate buffer, $\mathrm{pH} 7.4$, with $1.5 \%$ sucrose). A pool of $20 \mu \mathrm{L}$ of haemolymph was collected from five different samples and kept at $4{ }^{\circ} \mathrm{C}$ overnight. All samples were centrifuged at $1700 \times g$ for 5 min and the supernatant removed. The pellets were rinsed in PBS with $1.5 \%$ sucrose, post-fixed with $1 \%$ osmium tetroxide in $0.1 \mathrm{M}$ PBS for $2 \mathrm{~h}$ at $4{ }^{\circ} \mathrm{C}$, then rinsed in the same buffer. The dehydration of pellets in a graded acetone series was followed by embedding in epoxy resin (Merck Life Science, Milan, Italy). Ultrathin sections, cut with a PT-PC Power Tome Ultramicrotome (RMC Boeckeler, Groot-Ammers, The Netherlands, were examined with a Jeol JEM 1400 Plus electron microscope (Microscopy and Microanalysis Centre, CM2, Laboratory of Transmission Electron Microscopy-University of Calabria, Italy) at $60 \mathrm{kV}$. Measurements were taken from the digitised images using ImageJ and processed as means \pm standard error. 


\section{Results}

\subsection{Morphology and Ultrastructure of Haemocytes}

Four populations of circulating haemocyte types are identified in the haemolymph of T. molitor comparing their staining properties and morphology under light microscopy after May-Grünwald Giemsa staining (Figure 1A-Q), and ultrastructural analyses (Figures 2-7).

Prohaemocytes are immature and blast-like-cells in the haemolymph (Figure 1A-D). They appear variable in size, from 5 to $8 \mu \mathrm{m}$ in diameter, depending on the maturation degree, and spherical in shape. The nucleus/cytoplasm ratio is 0.8 in section. The immature chromatin of the central eosinophilic nucleus is coloured from pink to violet (after May-Grünwald Giemsa staining). A limited layer of neutral cytoplasm without granules surrounds the nucleus. TEM analyses show a well-defined euchromatic nucleus, from 4 to $6 \mu \mathrm{m}$ in diameter, and one or more prominent nucleoli, a homogeneous cytoplasm filled with a very low number of organelles such as mitochondria and rough endoplasmic reticulum (RER) (Figure 2A).

Plasmatocytes appear as elongate or spindle-shaped cells from 9 to $15 \mu \mathrm{m}$ in length and from 3 to $5 \mu \mathrm{m}$ in diameter in the ultimate stage of differentiation (Figure 1F-H). Their cytoplasm is neutral to basophilic (blue after May-Grünwald Giemsa staining) with small granules. Ultrathin sections of plasmatocytes show the lobate euchromatic nucleus $(2.6 \times 3.3 \mu \mathrm{m}$ in diameter) with a well-developed nucleolus (Figure 2B-D). Numerous organelles such as a well-developed RER, Golgi complexes and numerous elongate mitochondria (up to $1 \mu \mathrm{m}$ ) occur in the cytoplasm (Figure 2B,D). A low number of electron lucent vacuoles $1 \mu \mathrm{m}$ in diameter are also present (Figure 3B,C). The plasmatic membrane extends a variable number of filopodia (Figure 2B).

Oenocytoids are compared to the other cell types encountered in the haemolymph. They are elliptical cells characterised by an eccentric nucleus. The nucleus/cytoplasm ratio is approximatively 0.4 in section (Figure 1J-L). The cytoplasm appears homogeneous and neutral or slightly basophilic (blue) in LM. The ultrastructural analyses show cells, approximately $5 \times 15 \mu \mathrm{m}$ in diameter, with few organelles in the cytoplasm such as small mitochondria, free ribosomes, rough endoplasmic reticulum, Golgi complex and some multivesicular bodies (Figure 2F,G). The nucleus ( $4 \mu \mathrm{m}$ in diameter) is small and heterochromatic.

Granular cells are usually elongated, with an acidophilic nucleus (red after MayGrünwald Giemsa method staining) (Figure $1 \mathrm{~N}-\mathrm{Q}$ ) and the cytoplasm slightly basophilic (blue). Ultrathin sections show cells from 8 to 11 in length and from 3 to 6 in width (Figure 2D,E). The main distinctive feature is the presence in the cytoplasm of large granules, which are electron dense round vesicles with a diameter from $0.4 \mu \mathrm{m}$ to $0.9 \mu \mathrm{m}$, storing homogenous or structured tubular elements (Figure 2D,E). 

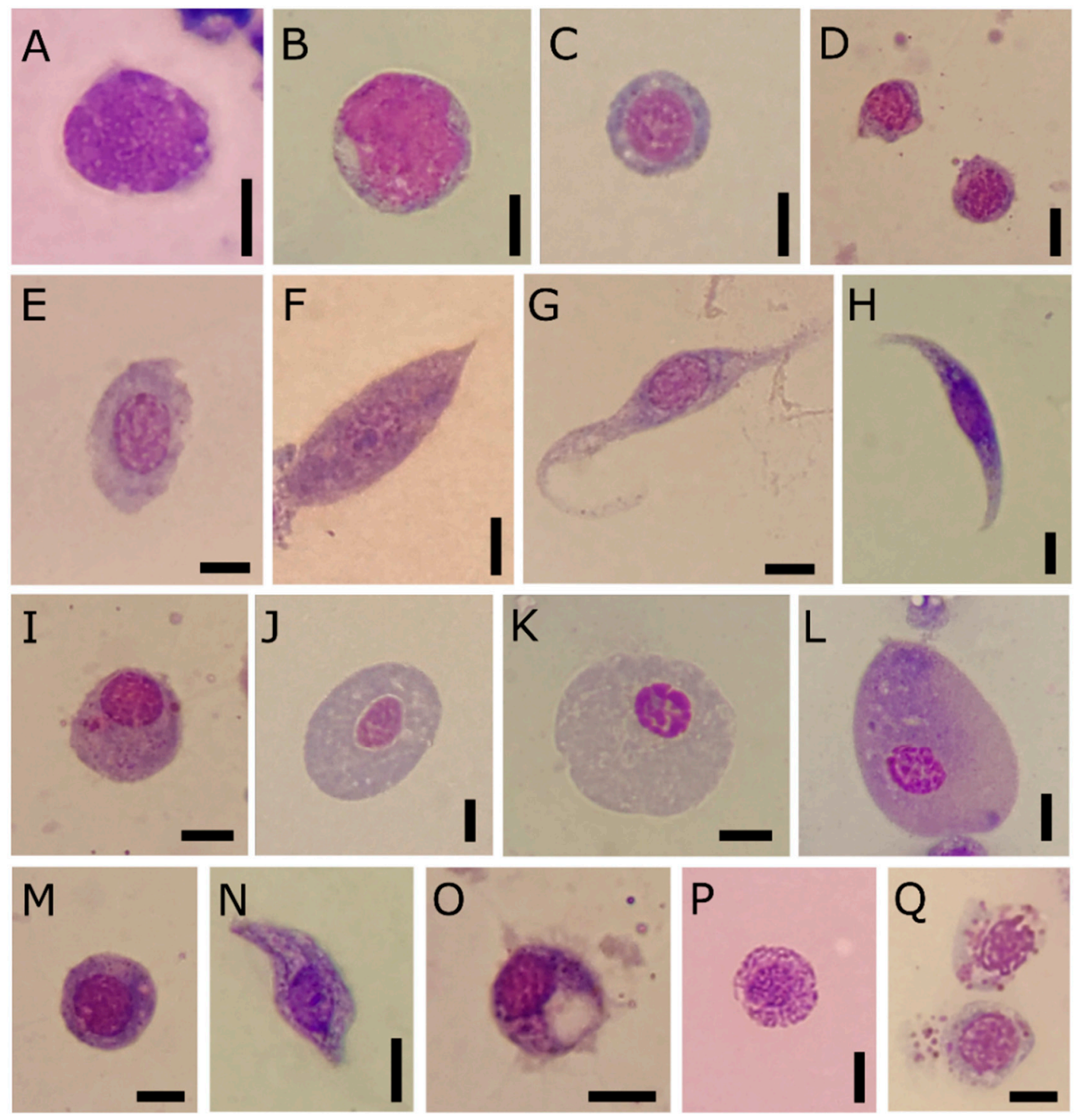

Figure 1. Light micrographs of haemolymph smears from T. molitor, May-Grünwald Giemsa stained. The metachromasia reveals specific morphological properties of different types. (A-D) Prohaemocytes. (E) Early plasmatocytes with large cytoplasm and heterochromatic nucleus. $(\mathbf{F}-\mathbf{H})$ Plasmatocytes as elongate cells with mature chromatin and eosinophilic cytoplasm (F), or spindle-shaped $(\mathbf{G}, \mathbf{H})$ with small basophilic granules in the cytoplasm. (I) Immature oenocytoid with eccentric nucleus and eosinophilic granules. (J-L) Differentiated oenocytoids with low nuclear-to-cytoplasmic ratio and homogenous cytoplasm. (M) Intermediate figure with basophilic cytoplasm and eosinophilic granules. (N-O) Circulating granular cells appear elongated in shape with large basophilic granules or round in shape and with eosinophilic granules (P), easily lysed and degranulated (Q). Bars: $5 \mu \mathrm{m}$. 

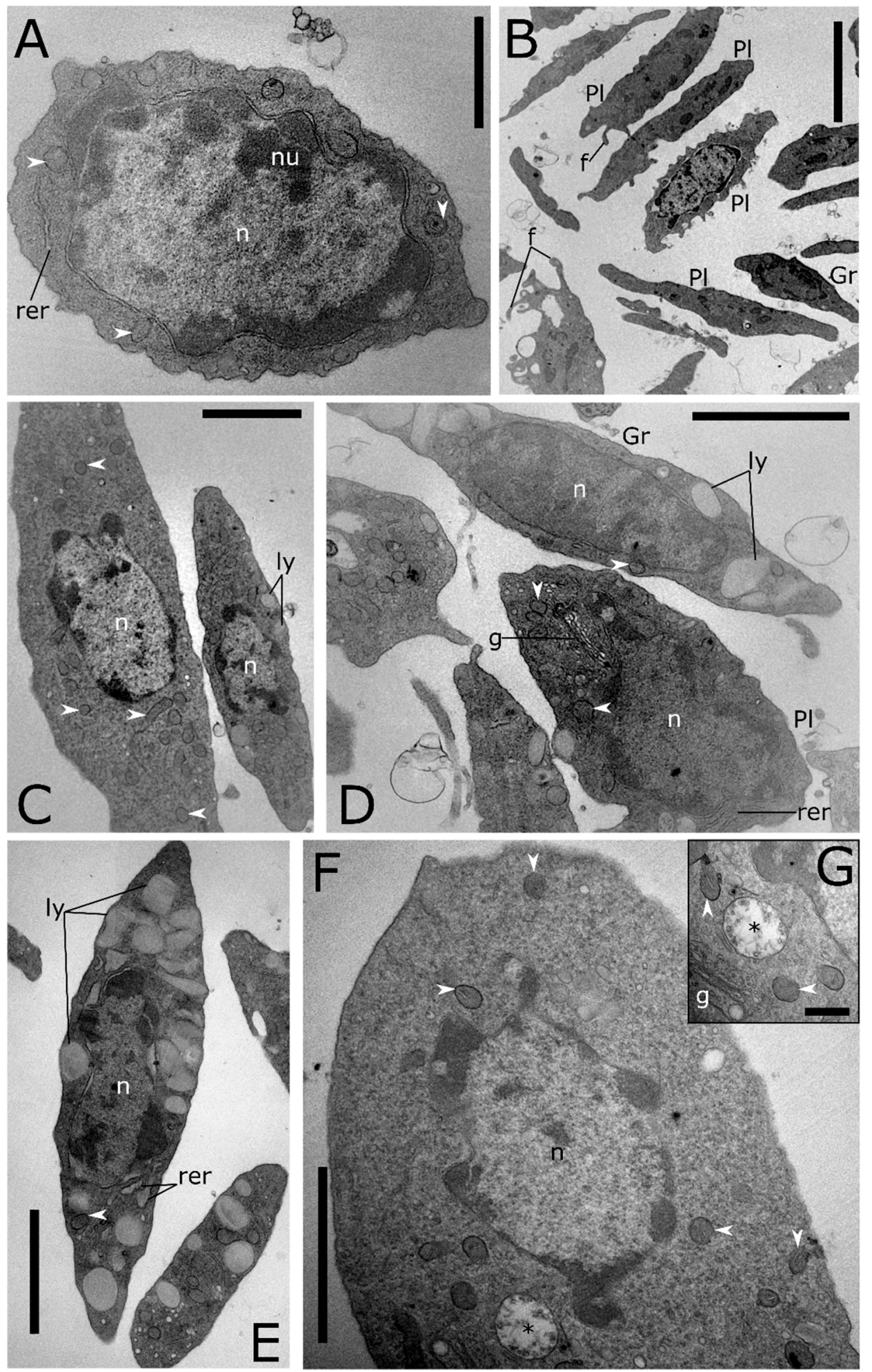

Figure 2. Transmission electron micrographs of haemocyte cross sections from T. molitor. (A) Prohaemocyte. (B) Plasmatocytes ( $\mathrm{Pl})$ and a granular cell $(\mathrm{Gr})$. (C) Longitudinal section of plasmatocytes. (D) Granular cells (Gr) with electron-dense granules (ly) in the cytoplasm and plasmatocytes (Pl) with an evident Golgi apparatus (g). (E) Granular cell with granules (ly) storing homogenous electron-dense material. (F) Oenocytoid. (G) Detail of the oenocytoid showing multivesicular body (asterisk) and Golgi complex (g); n: nucleus, nu: nucleolus, rer: rough endoplasmic reticulum, white arrowheads: mitochondria. Bars: $5 \mu \mathrm{m}(\mathbf{B}) ; 2 \mu \mathrm{m}(\mathbf{C}-\mathbf{F}) ; 1 \mu \mathrm{m}(\mathbf{A}) ; 500 \mathrm{~nm}(\mathbf{G})$. 
A high level of cell-to-cell variability is found within these four populations of haemocytes. Intermediate cell stages sharing features related to different types are commonly recorded at LM (Figure 1E,I,M) and TEM analyses (Figure 3). The variability concerning the cytoplasmic compartment suggests cellular maturation throughout different functional stages (Figure 3A-E). In some cases, the rough endoplasmic reticulum (RER) is welldeveloped and filled the cytoplasm indicating an active protein biosynthesis (Figure 3A,D). Filopodia appear as finger-like processes at the plasmatic membrane level (Figure 3C). Lipid droplets closely associated with mitochondria and endoplasmic reticulum (Figure 3B,C) are found in the population of haemocytes identified as plasmatocytes. Electron-dense granules closely associated with mitochondria are evident in the cytoplasm of haemocytes identified as granular cells (Figure 3E). A number of vesicles are evident in the cytoplasm (Figure 4A-E) close to the trans cisterna of the Golgi complex (Figure 4A) likely related to the cellular vesicular trafficking, which involves endo (Figure $4 \mathrm{~B}, \mathrm{C}$ ) and exocytic (Figure 5E) pathways, lysosomes and early and late endosomes including multivesicular bodies (MVBs) (Figure 4A,C-F). MVBs (approximatively $1 \mu \mathrm{m}$ in diameter) were clearly identifiable adjacent to the plasma membrane trapping numerous intraluminal vesicles (44 $\pm 1 \mathrm{~nm}$ in diameter, $\mathrm{n}=35$ ) (Figure $4 \mathrm{~A}, \mathrm{~B}, \mathrm{E}, \mathrm{F})$. The mechanism for packing of bioactive molecules into exosomes, through vesicles budding and pinching off into the MVBs lumen, appears evident at different developmental levels in the cytoplasm (Figure 4D-F). MVBs are located close to the Golgi complex at the crossroads between the biosynthetic and endocytic routes of haemocytes (Figure 4A,E). Intraluminal vesicles are released in extracellular space by exocytic fusion of MVBs with the plasma membrane (Figure 5D). A variable number of granules occur in the cytoplasm. The primary type is an electron-dense round membrane-limited inclusion able in storing (Figure 5A,B,D) and exocyting (Figure 5E) enzymes, very abundant in the haemocytes identified as granular cells. The second type is an electron-opaque granule including densely packed microtubular elements (Figure 5C). Granules storing glycogen are also evident (Figure 5E). In the nucleus, the amount of heterochromatin is most abundant in cells that are less or not active. 


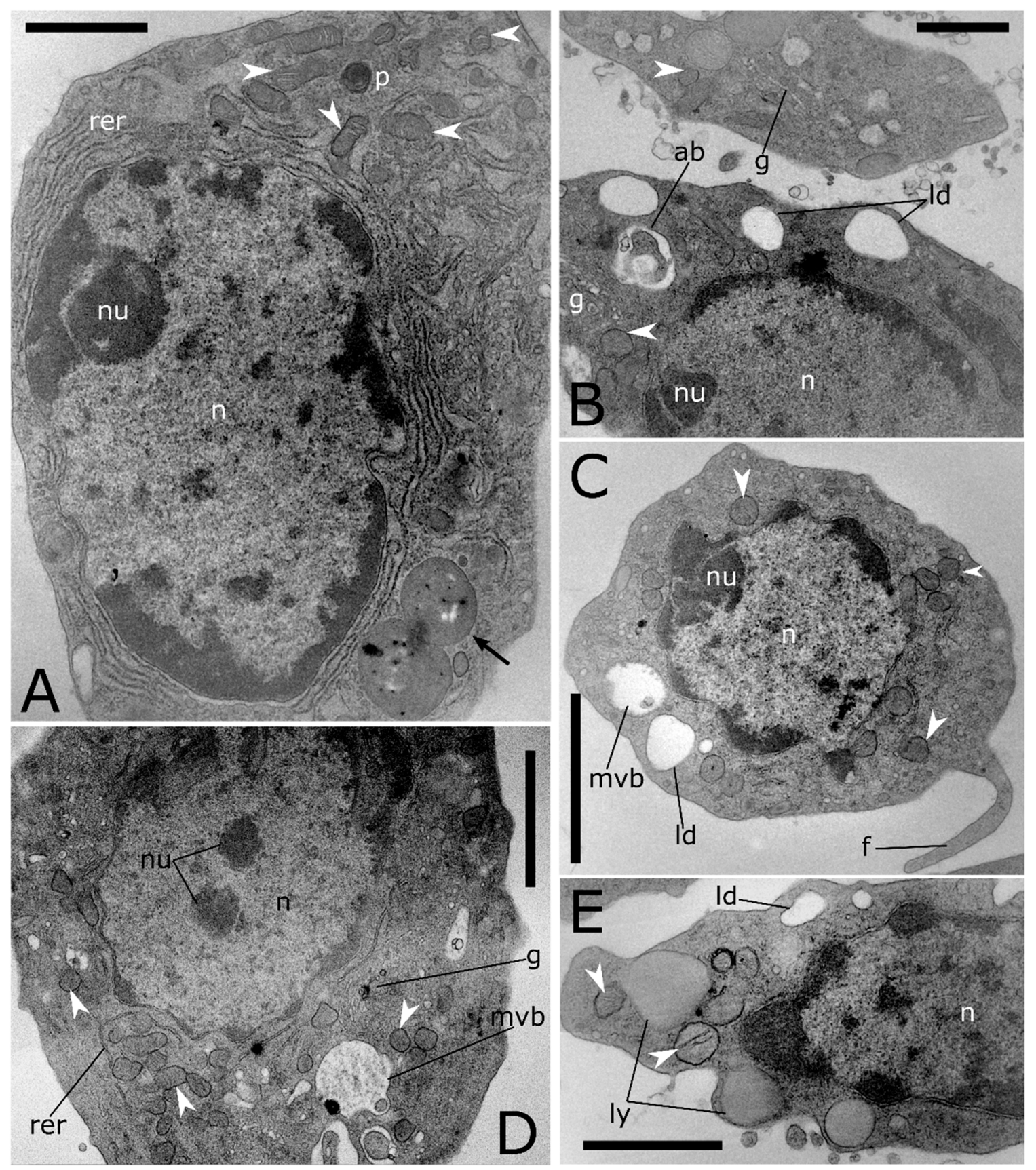

Figure 3. Transmission electron micrographs of haemocyte cross sections from T. molitor. (A) Intermediate haemocyte stage showing a large nucleus and a well-developed rough endoplasmic reticulum (rer). Granules with electron dense material (black arrow) are visible in the cytoplasm. (B) Plasmatocytes showing numerous small electron-lucent lipid droplets (ld) and an autophagic body (ab). (C) Transversal section of immature plasmatocytes showing an electron-lucent vesicle (ld) and a multivesicular body (mvb); plasmatic membrane is prolonged in a filopodium (f). (D) Intermediate cell stage without granules showing numerous mitochondria (white arrowheads), Golgi complex (g) and rough endoplasmic reticulum (rer). (E) Granular cell showing electron-dense granules (ly) and electron-lucent vesicles (ld). n: nucleus, nu: nucleolus, p: peroxisome. Bars: $2 \mu \mathrm{m}(\mathbf{D}) ; 1 \mu \mathrm{m}(\mathbf{A}-\mathbf{C}) ; 500 \mathrm{~nm}(\mathbf{E})$. 

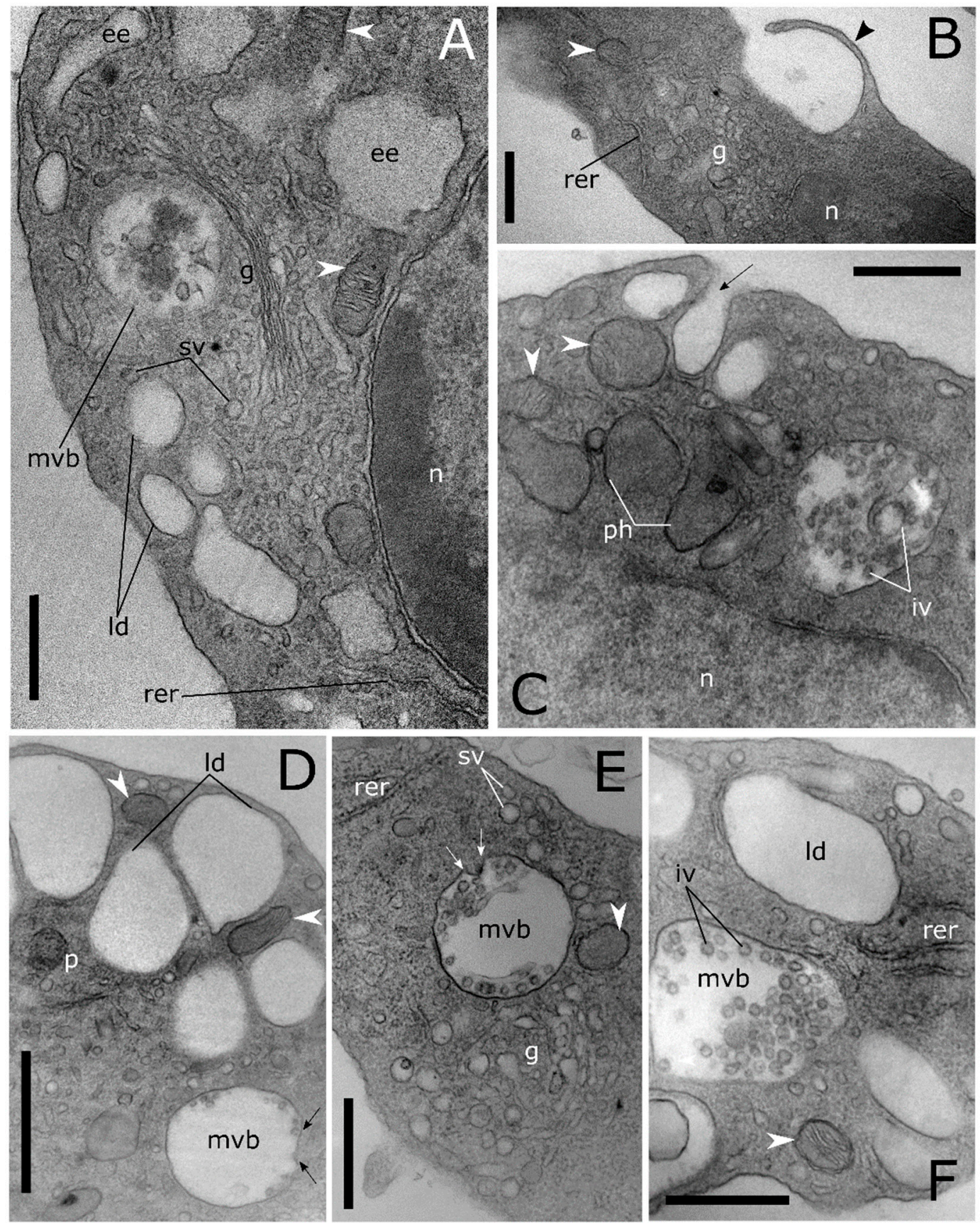

Figure 4. Transmission electron micrographs of cytoplasmic compartment in T. molitor haemocytes. (A) Cytoplasmic compartment showing Golgi complex (g) with secretory vesicles (sv), early endosome (ee), multivesicular body (mvb) and rough endoplasmic reticulum (rer). (B) Magnification of plasmatic membrane showing a phagocytic process through pseudopodium formation (black arrowhead). (C) Cross section showing a pinocytotic process through the plasmatic membrane invagination (black arrow). In the cytoplasm, macroautophagic processes are evident. Phagophores (ph) appear in a cup-shaped structure that engulfs a portion of the cytoplasm to form an autophagic body. (D-F) Multivesicular bodies $(\mathrm{mvb})$ limiting intraluminal vesicles (iv) at the early $(\mathbf{D}, \mathbf{E})$ and late $(\mathbf{A}, \mathbf{C}, \mathbf{F})$ level of the biogenesis process. Arrows $(\mathbf{D}, \mathbf{E})$ indicate intraluminal vesicles formed by budding of the limiting membrane of late endosomes. ld: lipid droplet, n: nucleus, p: peroxisome, white arrowheads: mitochondria. Bars: $1 \mu \mathrm{m}(\mathbf{D}) ; 500 \mathrm{~nm}(\mathbf{A}-\mathbf{C}, \mathbf{E}, \mathbf{F})$. 

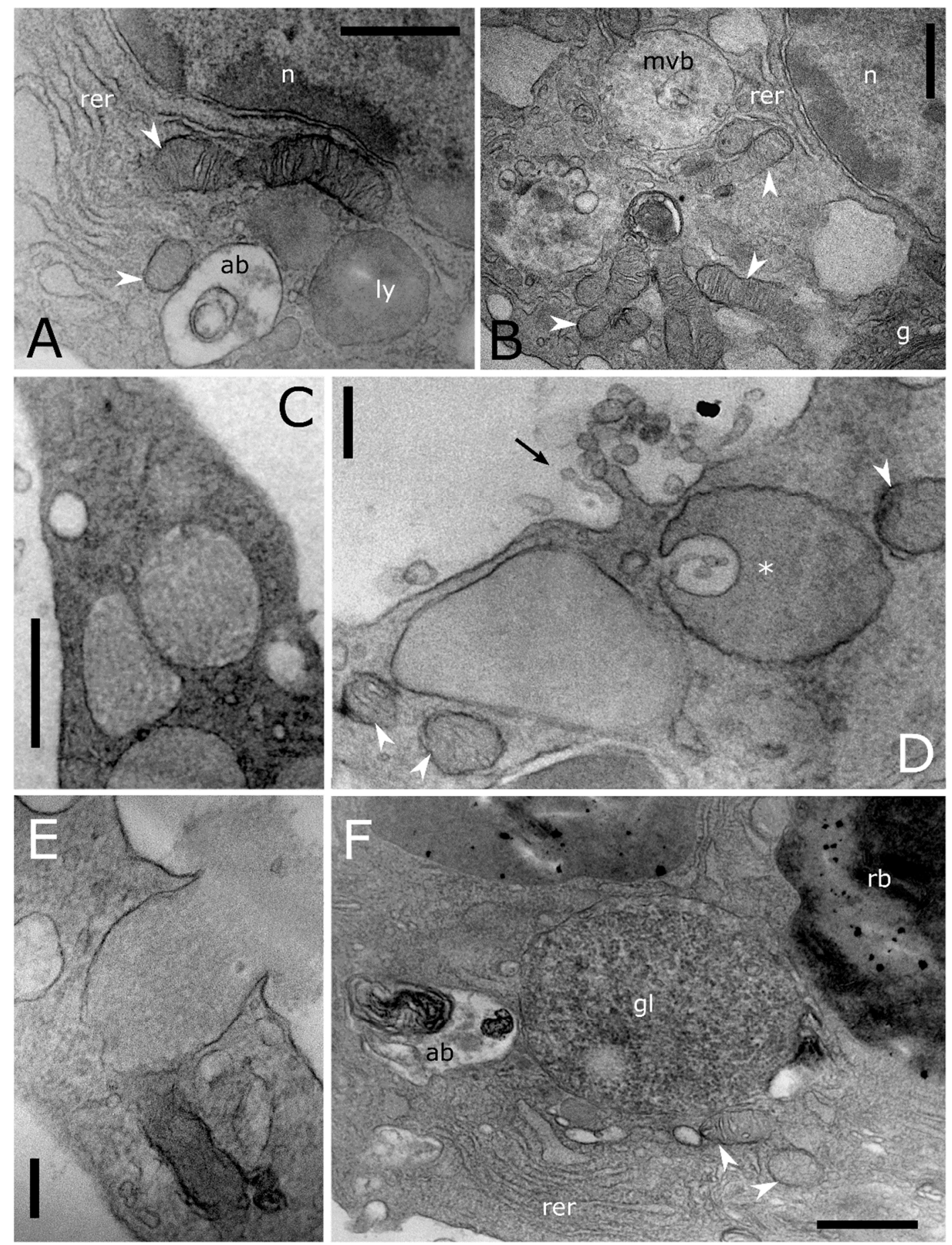

Figure 5. Transmission electron micrographs of cytoplasmic compartment in T. molitor haemocytes. (A,B) Details showing enlarged rough endoplasmic reticulum (rer), elongated mitochondria (white arrowheads) with evident cristae, autophagic body (ab), a granule (ly) storing homogeneous electron dense content and a multivesicular body (mvb). (C) Granules storing tubular elements. (D) Exosomes (black harrow) released in extracellular space by exocytic fusion of the multivesicular body with the plasma membrane. The asterisk indicates a microautophagic process. A lysosome invaginates and forms a bud sequestering cytoplasmic materials. (E) Degranulation process through the release of electron dense content in the extracellular medium. (F) Granule storing glycogen (gl) are closely adherent to a mitochondrion (white arrowhead). g: Golgi complex, n: nucleus, rb: residual body. Bars: $500 \mathrm{~nm}(\mathbf{A}-\mathbf{D}, \mathbf{F}) ; 200 \mathrm{~nm}(\mathbf{E})$. 
Ultrathin sections show also haemocytes with large autophagic compartments (Figure 6A-C). The different phases of the macroautophagic pathway are evident in the ultrathin sections from phagophores enveloping organelles (Figures $4 \mathrm{C}$ and $5 \mathrm{~A}$ ) to autophagosome (Figure $6 \mathrm{~A}-\mathrm{D}$ ) that fuses with lysosomes (Figure $5 \mathrm{~A}$ ) forming autolysosomes (Figure 6B,C). Autolysosomes contain digested cellular material and organelles at different stages of degeneration (Figure 6B-D). Moreover, the lysosome membrane pinches off into the organelle lumen and engulfs cytoplasmic material forming microautophagic bodies (Figure 5D). Myelin-like figures, which represent the results of autophagic degradation of membranous cellular components were evident (Figures 5F and 6A). Apoptotic (Figure 7A-C), degranulated (Figure 7D) and necrotic haemocytes (Figure 7E) occurring in the haemolymph are entrapped from other circulating haemocytes (Figure 7E,F). Cells occurring in various phases of mitotic division (Figure $8 \mathrm{~A}-\mathrm{C}$ ) indicate a turnover of haemocytes.
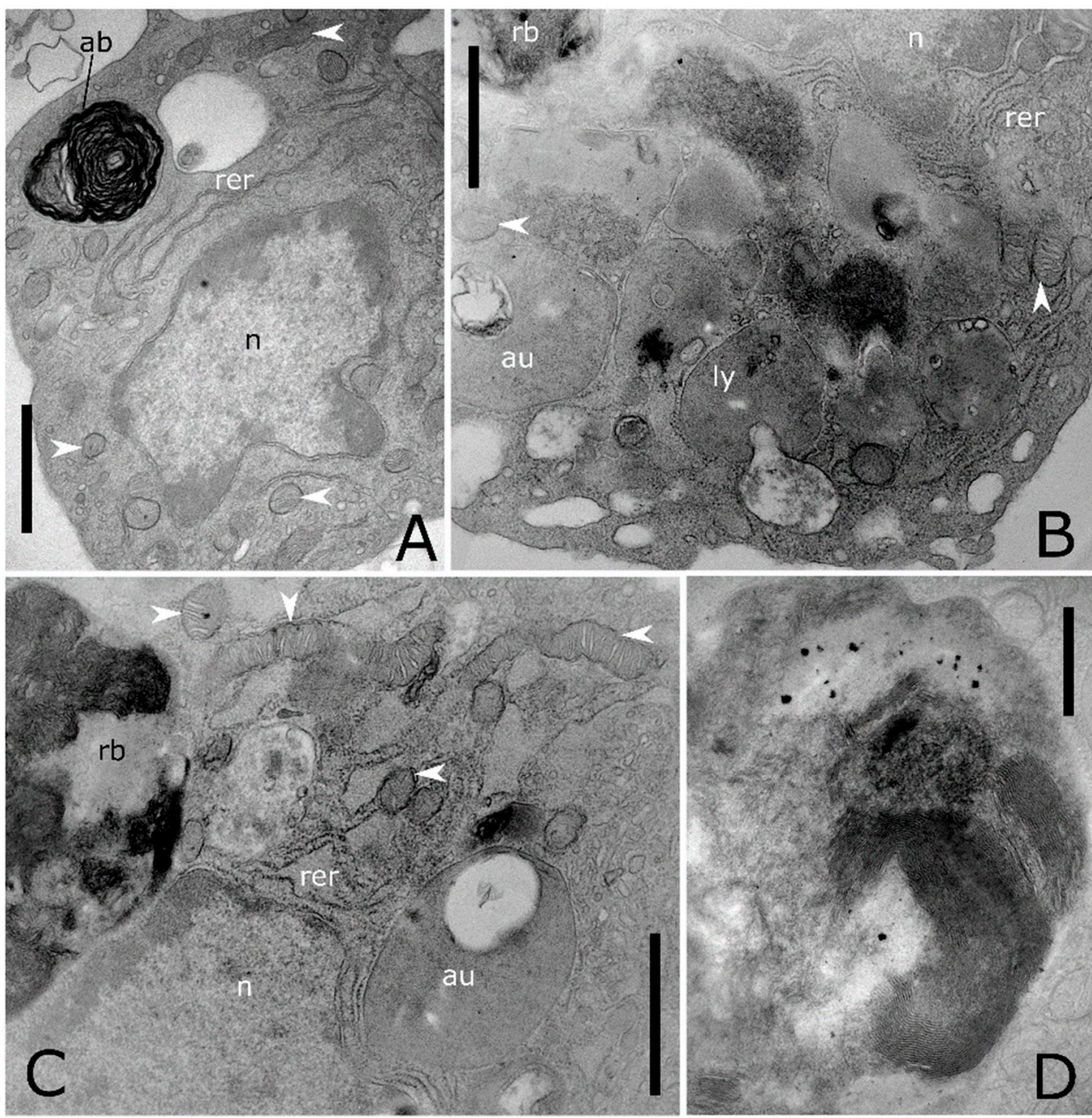

Figure 6. Ultrastructure of autophagic processes in T. molitor haemocytes. (A) Cytoplasm showing an autophagic body $(\mathrm{ab})$ with electron dense myelinic figures inside. (B) Magnification of the cytoplasm showing lysosome (ly) at different stages of maturation, fusing with phagosome, featured by electron lucent appearance and storing amorphous content. (C) Residual body (rb) storing packed membranes and an autolysosome (au). (D) Detail of a residual body, electron dense content with evident myelinic figures. n: nucleus, rer: rough endoplasmic reticulum, white arrowheads: mitochondria. Bars: $1 \mu \mathrm{m}$ (A-C); $500 \mathrm{~nm}(\mathbf{D})$. 

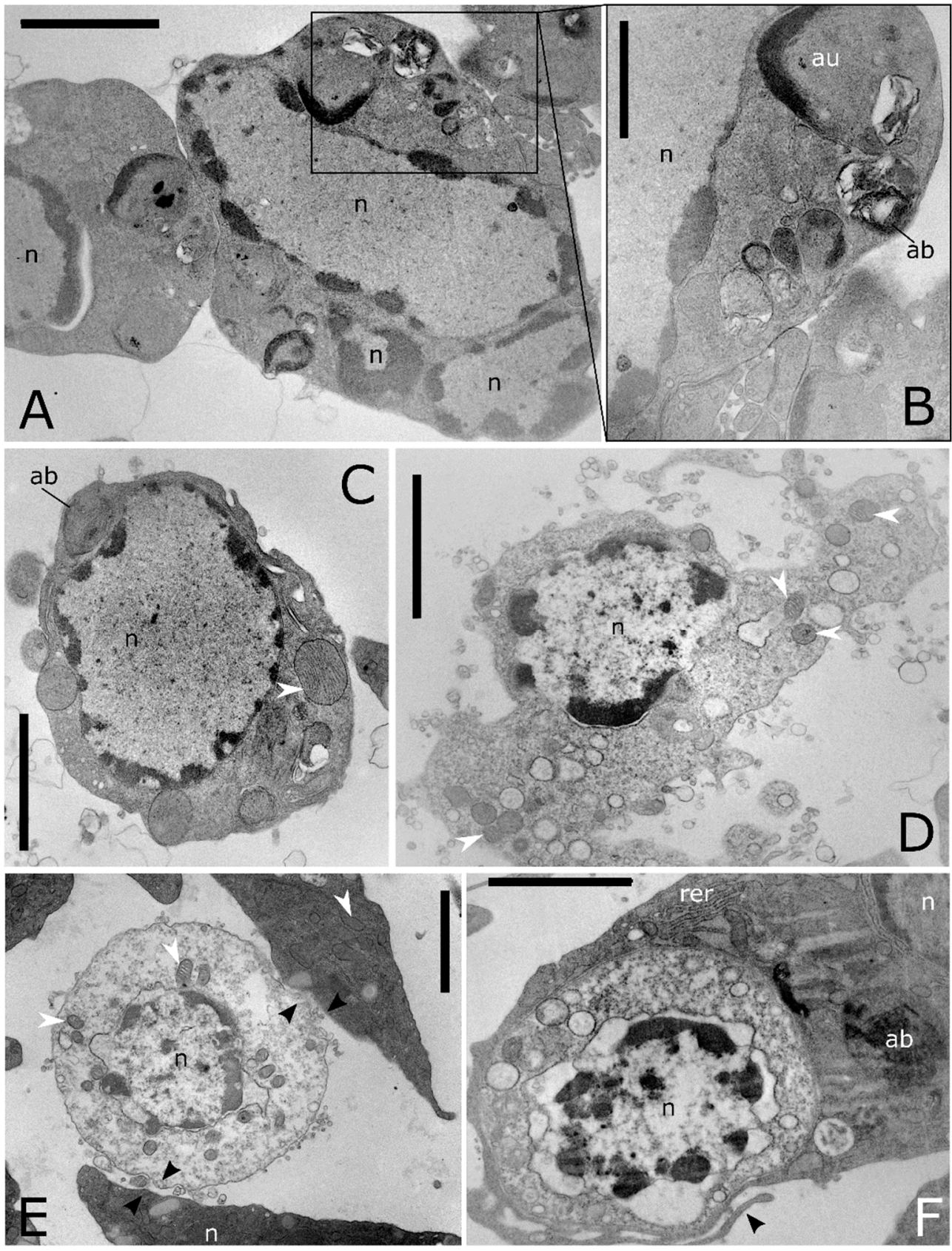

Figure 7. Ultrastructure of cell death in T. molitor haemocytes. (A) A cluster of apoptotic haemocytes. The chromatin condensed in patches under the inner nuclear envelope, nucleus and the plasma membrane blebbing is followed by separation of cell and nuclear fragments into apoptotic bodies. (B) Detail of (A) showing numerous macroautophagic body (ab) containing myelinic figures. (C) Apoptotic cell showing condensed chromatin near nuclear pores, enlarged mitochondria (white arrowhead) and macroautophagic bodies (ab). (D) Necrotic haemocytes with vacuolated cytoplasm, releasing cellular content in the extracellular environment. (E) Haemocyte at the early stage of necrosis, showing swelling of the external nuclear envelope and mitochondrial cristae, adhering trough the plasmatic membrane to other haemocytes (black arrowhead). (F) Cross section shows a phagocytic haemocyte wrapping a necrotic cell through prolongations of the cytoplasm (black arrowhead). au: autolysosome, n: nucleus, rer: rough endoplasmic reticulum, white arrowheads: mitochondria. Bars: $2 \mu \mathrm{m}(\mathbf{A}-\mathbf{F}) ; 1 \mu \mathrm{m}(\mathbf{B})$. 


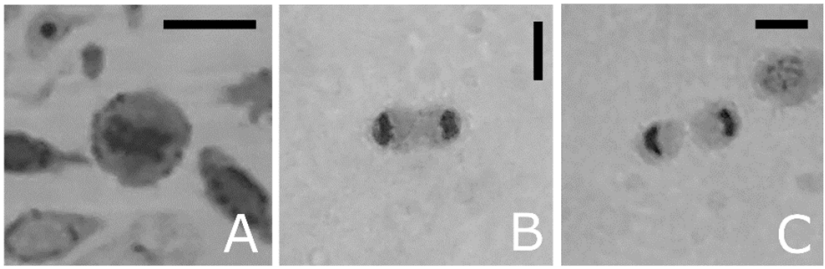

Figure 8. Light microscopy images of haemocyte semithin sections from T. molitor, showing mitotic stages. (A) Metaphase. (B) Telophase, (C) Cytokinesis. Bars: $5 \mu \mathrm{m}$.

\subsection{Cytochemical and Cytoenzymatic Analyses}

Haemocytes of T. molitor display diverse responses to cytochemical and cytoenzymatic analyses (Figure 9). Granular cells and plasmatocytes are able to accumulate the neutral red dye (Figure 9D), revealing acidic vacuolar compartments and the nature of granules as lysosomes. The circulating haemocytes are only partly positive to the PAS reaction, revealing a different distribution of carbohydrates among cell types (Figure 9H,I). PAS reaction positivity is observed in the cytoplasmic compart outside of granules. Oenocytoids (Figure 9I) are also recorded as PAS positive, while variable responses are observed for other cell types. Cytoenzymatic analysis of haemocytes reveals the presence of prophenoloxidase in almost all cell types. The strongest reaction of the zymogen activation is observed in granular cells (Figure 9E,F), granules of which were stained orange/brown. The controls did not show any reaction product (Figure 9G).
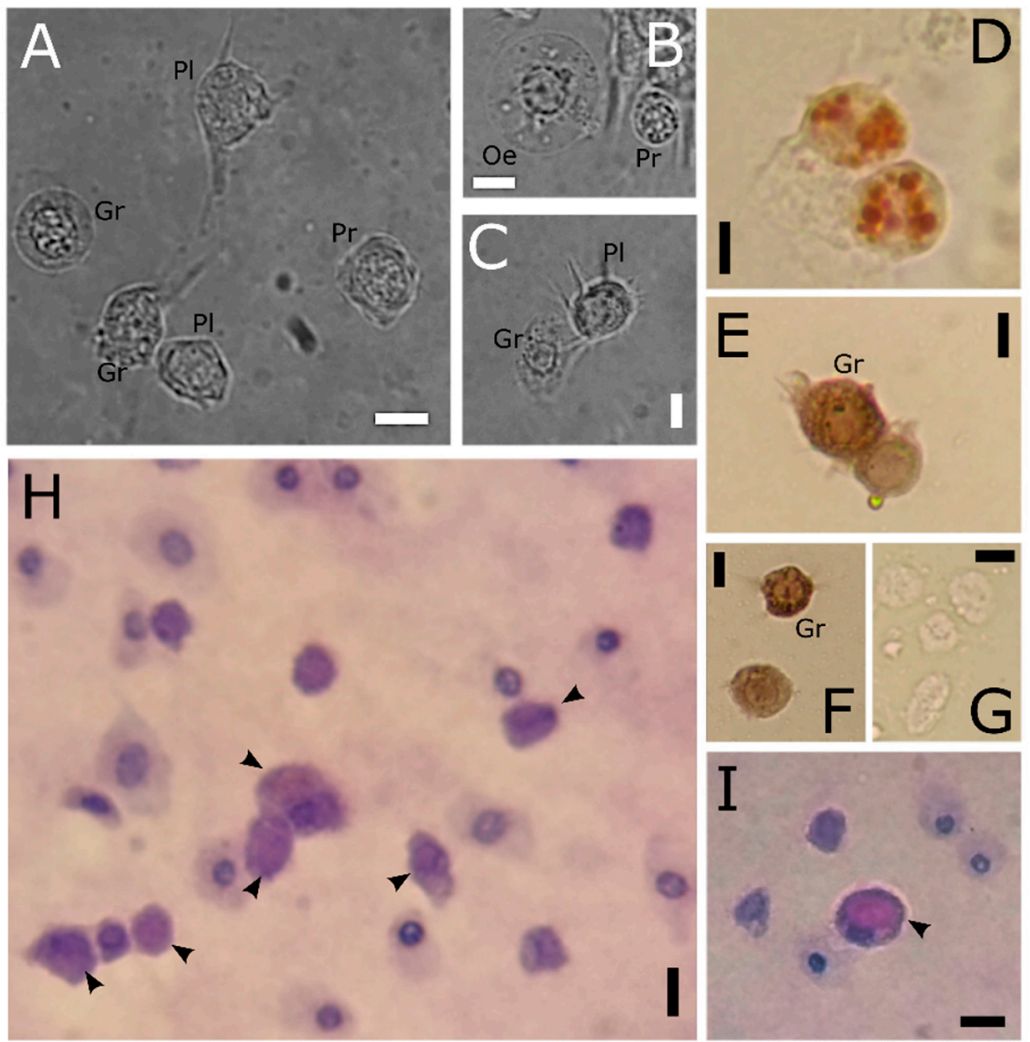

Figure 9. Light microscopy images of haemolymph smears from T. molitor. (A-C) In vivo haemocytes. (D) Haemocytes stained with neutral red to highlight lysosomes in red. (E-G) PO-haemocyte activity. Haemocytes showing cytoplasmic localisation of phenoloxidase in granular cells (E,F) and control (G). (H,I) PAS staining. Positive sites (arrowheads) indicating stored carbohydrates. Gr: granular cells; Oe: oenocytoids; Pl: plasmatocytes; Pr: prohaemocytes. Bars: $5 \mu \mathrm{m}$. 


\section{Discussion}

This study provides a comprehensive description of the haemocyte ultrastructure in $T$. molitor adults. The results highlighted four morphological types of circulating haemocytes we referred to as prohaemocytes, plasmatocytes, granular cells and oenocytoids according to a previous study carried out by using fluorescence and scanning electron microscopy [39]. Actually, circulating haemocytes have been described in a low number of coleopteran species. Nevertheless, morphology and function are rather variable among the species described so far with different life histories [42-44]. Four to seven morphologically distinct types were identified, named prohemocytes, plasmatocytes, granular cells, coagulaocytes, oenocytoids, adipohemocytes and spherulocytes in haemolymph of Coccinellidae [45], Curculionidae [46], Melolonthidae [47], Scarabeaidae [10,48], Chrysomelidae [49] and Carabidae $[12,13,41,50]$. Granular cells, plasmatocytes and oenocytoids have been indicated as the main cell types involved in the phagocytosis in both adults and larvae [10,12,45,46,48]. Here, we found that granular cells are the main PO-positive circulating haemocytes of T. molitor, as observed in previous studies $[40,51,52]$. Thus we assume that they may be involved in the melanisation cascade or in aggregation processes, such as encapsulation and nodulation of pathogens [53]. Moreover, the large amount of lysosomes found in the granular cells confirmed the capability to internalise foreign organisms into a phagosome as indicated in previous studies $[39,54]$ and a role in removal and degradation of necrotic cells and apoptotic bodies as observed in ultrathin sections.

The haemocyte classification is still a controversial topic and limitations to perform a comparative analysis among the low number of species so far described are partly due to the differences of investigation methods besides the species-specific variability [42]. Moreover, there is an intrinsic cell-to-cell variability related to the haemocyte function that is misidentified as an indicator of morphological diversity. Previous studies hypothesised a separate immutable cell lines differentiating from haemopoietic organs or circulating prohaemocytes $[4,55,56]$. However, cytochemical and ultrastructural analyses performed in T. molitor allowed us to observe phenotypic variation within each cellular population. This variability deals with the assumption of a limited number of circulating haemocyte types involved in cellular defences, that we considered different stages with separate functions. As a result, prohaemocytes are only less differentiated cells, as observed in our ultrastructural analyses, instead of multipotent stem cells, coherently with previous studies $[13,17,57,58]$. Indeed, the conversion of already differentiated circulating haemocytes into another cell type has been observed in vitro in plasmatocytes of T. molitor, Periplaneta americana, Galleria mellonella [59], D. melanogaster [60] and in prohemocytes of Bombyx mori [61]. Previous studies showed that morphological features, such as the size of nucleoli indicate a high proteosynthetic activity closely related to the ability of a cell to differentiate into another cell type $[62,63]$. According to this finding, haemocytes here indicated as plasmatocytes, which show prominent nucleoli in an euchromatic nucleus and a well-developed rough endoplasmic reticulum, should be considered as one of the earliest stages of functionally differentiated cells. On the contrary, oenocytoids should have lowered potential to turn into another type. Thus, we assume that the morphological differences observed among and within the cellular populations of T. molitor may be closely related to the variation of the cell function during its life cycle. This hypothesis is supported by the high number of haemocytes found in both smears and ultrathin sections, showing very similar subcellular structure and micro and macroautophagic activities involved to maintaining the regular homeostatic turnover of organelles [64,65]. Moreover, the evidence of mitotic circulating cells suggests that haemocyte proliferation occurs to replace apoptotic and necrotic haemocytes and not just as a response following infection as observed in D. melanogaster [58]. Future studies may include techniques such as single cell RNA-sequencing to reveal hidden complexity and achieve a more fine-grained characterisation of haemocyte types related to their function as predicted from gene expression patterns. However, up to now, this technique has to our knowledge only been applied to a few insect model organisms such as D. melanogaster [66] and Anopheles gambiae [67]. 
The PAS positive-stained cells and ultrastructure of granules storing glycogen and lipids indicated that haemocytes of T. molitor may be involved in the regulation of carbohydrate and lipid levels in the haemolymph. As observed in larvae of D. melanogaster, lamellocytes become dependent on a massive supply of carbohydrates to perform the encapsulation of parasitoid wasp eggs [68]. Thus, autophagy also promotes cellular homeostasis by facilitating nutrient utilisation. The sequestration of polysaccharide such as glycogen in the autophagosomes and its subsequent degradation in the autolysosomes is a selective process activated under conditions of demand for massive production of glucose as observed in vertebrates [69] and insects [70]. Indeed, the plasticity of the immune response requested to face pathogens during the insect life has maintenance costs [71] and leads to a systemic metabolic switch, redirecting the metabolic resources to the activated immune system. As neuropeptides play an important immunotropic role in the regulation of the insect cellular and humoral responses promoting the mobilisation of energetic sources, such as the breakdown of glycogen into circulating carbohydrates $[72,73]$ and lipid [74], T. molitor may be a useful model to study the endocrine regulation of the immune responses in insects.

The large number of MVBs found in the cytoplasmic compartment provided evidences of a cell-to-cell communication involving exosomes. MVBs are late endosomes containing intraluminal vesicles, formed through direct inward budding of their limiting membranes, that move up to the cell surface, fuse with the plasma membrane and release singlemembrane exosomes outside the cell [75]. In insects, the role of exosomes in cell polarity and intracellular communication is a new emerging topic [76-82]. Exosomes have been isolated for the first time from the haemolymph of Allomyrina dichotoma (Coleoptera: Scarabaeidae) [83]. Thus, further investigation on the molecular content of these vesicles in T. molitor will improve knowledge about cell-to-cell communication.

This study contributes to increasing knowledge on the function and morphology of haemocytes in T. molitor. The ultrastructure will be a baseline for further studies aimed to clarify the relationship between structure and function of the subcellular compartment in haemocytes and their role to transfer information through the haemocoel. Moreover, our findings validate the suitability of haemocytes in T. molitor to study cellular evolutionary conserved processes, such as vesicular trafficking and macro and microautophagy.

Author Contributions: Conceptualization, A.G. and M.L.V.; methodology: A.G. and M.L.V.; formal analysis and investigation: A.G. and M.L.V.; writing-original draft preparation: A.G. and M.L.V.; writing-review and editing: A.G., J.K. and M.L.V.; funding acquisition and supervision: A.G. All authors have read and agreed to the published version of the manuscript.

Funding: This research was funded by the Italian Ministry of Education, University and Research (MIUR) (grant $\mathrm{n}^{\circ}$ UA.00.2014.EX60).

Institutional Review Board Statement: Ethical review and approval were waived for this study, as beetles are not considered as laboratory animals according to EU Directive 2010/63.

Data Availability Statement: All microscopy data are available in the Laboratory of Morphofunctional Entomology, Department of Biology, Ecology and Earth Science, University of Calabria, Italy.

Acknowledgments: Authors thank Francesco Carbone for image processing.

Conflicts of Interest: The authors declare no conflict of interest. The funders had no role in the design of the study; in the collection, analyses, or interpretation of data; in the writing of the manuscript, or in the decision to publish the results.

\section{References}

1. Schulenburg, H.; Kurtz, J.; Moret, Y.; Siva-Jothy, M.T. Introduction. Ecological immunology. Philos. Trans. R. Soc. B Biol. Sci. 2009, 364, 3-14. [CrossRef]

2. Siva-Jothy, M.T.; Moret, Y.; Rolff, J. Insect Immunity: An Evolutionary Ecology Perspective. Adv. Insect Phys. 2005, 32, 1-48. [CrossRef]

3. Dubovskiy, I.M.; Kryukova, N.A.; Glupov, V.V.; Ratcliffe, N.A. Encapsulation and nodulation in insects. Invertebr. Surviv. J. 2016, 13, 229-246. 
4. Strand, M.R. The insect cellular immune response. Insect Sci. 2008, 15, 1-14. [CrossRef]

5. Lavine, M.D.; Strand, M.R. Insect hemocytes and their role in immunity. Insect Biochem. Mol. Biol. 2002, 32, 1295-1309. [CrossRef]

6. Rosales, C. Phagocytosis, a cellular immune response in insects. Invertebr. Surviv. J. 2011, 8, 109-131.

7. Hillyer, J.F.; Christensen, B.M. Characterization of hemocytes from the yellow fever mosquito, Aedes aegypti. Histochem. Cell Biol. 2002, 117, 431-440. [CrossRef] [PubMed]

8. Gábor, E.; Cinege, G.; Csordás, G.; Rusvai, M.; Honti, V.; Kolics, B.; Török, T.; Williams, M.J.; Kurucz, É.; Andó, I. Identifi-cation of reference markers for characterizing honey bee (Apis mellifera) hemocyte classes. Dev. Comp. Immunol. 2020, $109,103701$. [CrossRef] [PubMed]

9. Gillespie, J.P.; Kanost, M.R.; Trenczek, T. Biological mediators of insect immunity. Annu. Rev. Entomol. 1997, 42, 611-643. [CrossRef]

10. Giulianini, P.G.; Bertolo, F.; Battistella, S.; Amirante, G.A. Ultrastructure of the hemocytes of Cetonischema aeruginosa larvae (Coleoptera, Scarabaeidae): Involvement of both granulocytes and oenocytoids in in vivo phagocytosis. Tissue Cell 2003, 35, 243-251. [CrossRef]

11. Jiravanichpaisal, P.; Lee, B.L.; Söderhäll, K. Cell-mediated immunity in arthropods: Hematopoiesis, coagulation, melaniza-tion and opsonization. Immunobiology 2006, 211, 213-236. [CrossRef] [PubMed]

12. Giglio, A.; Battistella, S.; Talarico, F.F.; Brandmayr, T.Z.; Giulianini, P.G. Circulating hemocytes from larvae and adults of Carabus (Chaetocarabus) lefebvrei Dejean 1826 (Coleoptera, Carabidae): Cell types and their role in phagocytosis after in vivo artificial non-self-challenge. Micron 2008, 39, 552-558. [CrossRef] [PubMed]

13. Cavaliere, F.; Brandmayr, P.; Giulianini, P.G.; Vommaro, M.L.; Giglio, A. Harpalus (Pseudoophonus) rufipes as a model to study cellular and humoral immune defence strategies in coleopteran species. Invertebr. Surviv. J. 2019, 16, 92-104.

14. Tsakas, S.; Marmaras, V.J. Insect immunity and its signalling: An overview. Invertebr. Surviv. J. 2010, 7, $228-238$.

15. Hillyer, J.F. Insect immunology and hematopoiesis. Dev. Comp. Immunol. 2016, 58, 102-118. [CrossRef] [PubMed]

16. Meister, M. Blood cells of Drosophila: Cell lineages and role in host defence. Curr. Opin. Immunol. 2004, 16, 10-15. [CrossRef] [PubMed]

17. Honti, V.; Csordás, G.; Kurucz, É.; Márkus, R.; Andó, I. The cell-mediated immunity of Drosophila melanogaster: Hemocyte lineages, immune compartments, microanatomy and regulation. Dev. Comp. Immunol. 2014, 42, 47-56. [CrossRef] [PubMed]

18. Wilson-Sanders, S.E. Invertebrate Models for Biomedical Research, Testing, and Education. ILAR J. 2011, 52, 126-152. [CrossRef]

19. Adamski, Z.; Bufo, S.A.; Chowański, S.; Falabella, P.; Lubawy, J.; Marciniak, P.; Pacholska-Bogalska, J.; Salvia, R.; Scrano, L.; Słocińska, M.; et al. Beetles as Model Organisms in Physiological, Biomedical and Environmental Studies-A Review. Front. Physiol. 2019, 10, 1-22. [CrossRef] [PubMed]

20. Browne, N.; Heelan, M.; Kavanagh, K. An analysis of the structural and functional similarities of insect hemocytes and mammalian phagocytes. Virulence 2013, 4, 597-603. [CrossRef]

21. Salzet, M. Vertebrate innate immunity resembles a mosaic of invertebrate immune responses. Trends Immunol. 2001, 22, 285-288. [CrossRef]

22. Hoffmann, J.A.; Reichhart, J.M. Drosophila innate immunity: An evolutionary perspective. Nat. Immunol. 2002, 3, 121-126. [CrossRef]

23. Lagadic, L.; Caquet, T. Invertebrates in testing of environmental chemicals: Are they alternatives? Environ. Health Perspect. 1998, 106, 593-611. [CrossRef]

24. Berger, J. Preclinical testing on insects predicts human haematotoxic potentials. Lab. Anim. 2009, 43, 328-332. [CrossRef] [PubMed]

25. Vommaro, M.L.; Giulianini, P.G.; Giglio, A. Pendimethalin-based herbicide impairs cellular immune response and haemocyte morphology in a beneficial ground beetle. J. Insect Physiol. 2021, 131, 104236. [CrossRef] [PubMed]

26. Brady, D.; Grapputo, A.; Romoli, O.; Sandrelli, F. Insect cecropins, antimicrobial peptides with potential therapeutic ap-plications. Int. J. Mol. Sci. 2019, 20, 5862. [CrossRef] [PubMed]

27. Ng, W.K. Potential of mealworm (Tenebrio molifor) as an alternative protein source in practical diets for African catfish, Clarias gariepinus. Aquac. Res. 2001, 32, 273-280. [CrossRef]

28. Costa, S.; Pedro, S.; Lourenço, H.; Batista, I.; Teixeira, B.; Bandarra, N.M.; Murta, D.; Nunes, R.; Pires, C. Evaluation of Tenebrio molitor larvae as an alternative food source. NFS J. 2020, 21, 57-64. [CrossRef]

29. Paul, A.; Frederich, M.; Megido, R.C.; Alabi, T.; Malik, P.; Uyttenbroeck, R.; Francis, F.; Blecker, C.; Haubruge, E.; Lognay, G. Insect fatty acids: A comparison of lipids from three Orthopterans and Tenebrio molitor L. larvae. J. Asia Pac. Èntomol. 2017, 20, 337-340. [CrossRef]

30. Selaledi, L.; Mbajiorgu, C.A.; Mabelebele, M. The use of yellow mealworm (T. molitor) as alternative source of protein in poultry diets: A review. Trop. Anim. Health Prod. 2020, 52, 7-16. [CrossRef]

31. Peng, B.-Y.; Su, Y.; Chen, Z.; Chen, J.; Zhou, X.; Benbow, M.E.; Criddle, C.S.; Wu, W.-M.; Zhang, Y. Biodegradation of Polystyrene by Dark (Tenebrio obscurus) and Yellow (Tenebrio molitor) Mealworms (Coleoptera: Tenebrionidae). Environ. Sci. Technol. 2019, 53, 5256-5265. [CrossRef] [PubMed]

32. Brandon, A.M.; Gao, S.H.; Tian, R.; Ning, D.; Yang, S.S.; Zhou, J.; Wu, W.M.; Criddle, C.S. Biodegradation of Polyethylene and Plastic Mixtures in Mealworms (Larvae of Tenebrio molitor) and Effects on the Gut Microbiome. Environ. Sci. Technol. 2018, 52, 6526-6533. [CrossRef] 
33. Vigneron, A.; Jehan, C.; Rigaud, T.; Moret, Y. Immune Defenses of a Beneficial Pest: The Mealworm Beetle, Tenebrio molitor. Front. Physiol. 2019, 10, 138. [CrossRef] [PubMed]

34. Johnston, P.R.; Makarova, O.; Rolff, J. Inducible Defenses Stay up Late: Temporal Patterns of Immune Gene Expression in Tenebrio molitor. G3 Genes Genomes Genet. 2014, 4, 947-955. [CrossRef] [PubMed]

35. Zhu, J.Y.; Yang, P.; Zhang, Z.; Wu, G.X.; Yang, B. Transcriptomic immune response of Tenebrio molitor pupae to parasitiza-tion by Scleroderma guani. PLoS ONE 2013, 8, e54411.

36. Maistrou, S.; Paris, V.; Jensen, A.B.; Rolff, J.; Meyling, N.V.; Zanchi, C. A constitutively expressed antifungal peptide protects Tenebrio molitor during a natural infection by the entomopathogenic fungus Beauveria bassiana. bioRxiv 2018, 86, 26-33. [CrossRef] [PubMed]

37. Jones, J.C. A Study of Mealworm Hemocytes with Phase Contrast Microscopy. Ann. Èntomol. Soc. Am. 1954, 47, 308-315. [CrossRef]

38. Chung, K.-H.; Moon, M.-J. Fine Structure of the Hemopoietic Tissues in the Mealworm Beetle, Tenebrio molitor. Èntomol. Res. 2004, 34, 131-138. [CrossRef]

39. Urbański, A.; Adamski, Z.; Rosiński, G. Developmental changes in haemocyte morphology in response to Staphylococcus aureus and latex beads in the beetle Tenebrio molitor L. Micron 2018, 104, 8-20. [CrossRef]

40. Ling, E.; Shirai, K.; Kanehatsu, R.; Kiguchi, K. Reexamination of phenoloxidase in larval circulating hemocytes of the silk-worm, Bombyx mori. Tissue Cell 2005, 37, 101-107. [CrossRef] [PubMed]

41. Giglio, A.; Giulianini, P.G. Phenoloxidase activity among developmental stages and pupal cell types of the ground beetle Carabus (Chaetocarabus) lefebvrei (Coleoptera, Carabidae). J. Insect Physiol. 2013, 59, 466-474. [CrossRef]

42. Siddiqui, M.I.; Al-Khalifa, M.S. Circulating haemocytes in insects: Phylogenic review of their types. Pak. J. Zool. 2012, 44, 1743-1750.

43. Gilbert, L.I. Insect Hemocytes: Development, Forms, Functions, and Techniques; Gupta, A.P., Ed.; Cambridge University Press: Cambridge, UK, 1980; Volume 55, ISBN 9780511759987.

44. Ghoneim, K. Characterization of Qualitative and Quantitative Haemogram Parameters in Insects: Current Concepts and Future Prospects. Egypt. Acad. J. Biol. Sci. A Èntomol. 2019, 12, 9-63. [CrossRef]

45. Firlej, A.; Girard, P.A.; Brehlin, M.; Coderre, D.; Boivin, G. Immune Response of Harmonia axyridis (Coleoptera: Coccinellidae) Supports the Enemy Release Hypothesis in North America. Ann. Èntomol. Soc. Am. 2012, 105, 328-338. [CrossRef]

46. Manachini, B.; Arizza, V.; Parrinello, D.; Parrinello, N. Hemocytes of Rhynchophorus ferrugineus (Olivier) (Coleoptera: Curculionidae) and their response to Saccharomyces cerevisiae and Bacillus thuringiensis. J. Invertebr. Pathol. 2011, 106, $360-365$. [CrossRef]

47. Gupta, A.P. (Ed.) Hemocytes types, their structures, synonymies, interrelationships, and taxonomic significance. In Insect Hemocytes: Development, Forms, Functions and Techniques; Cambridge University Press: Cambridge, UK, 1979 ; pp. 85-127.

48. Hwang, S.; Bang, K.; Lee, J.; Cho, S. Circulating hemocytes from larvae of the Japanese rhinoceros beetle Allomyrina dichotoma (Linnaeus) (Coleoptera: Scarabaeidae) and the cellular immune response to microorganisms. PLoS ONE 2015, 10, e0128519. [CrossRef]

49. Phukan, M.; Hazarika, L.K.; Barooah, M.; Puzari, K.C.; Kalita, S. Interaction of Dicladispa armigera (Coleoptera: Chrysomelidae) haemocytes with Beauveria bassiana. Int. J. Trop. Insect Sci. 2008, 28, 88-97. [CrossRef]

50. Giglio, A.; Brandmayr, P.; Pasqua, T.; Angelone, T.; Battistella, S.; Giulianini, P.G. Immune challenges trigger cellular and humoral responses in adults of Pterostichus melas italicus (Coleoptera, Carabidae). Arthropod. Struct. Dev. 2015, 44, 209-217. [CrossRef] [PubMed]

51. Kurtz, J.; Sauer, K.P. Gender Differences in Phenoloxidase Activity of Panorpa vulgaris Hemocytes. J. Invertebr. Pathol. 2001, 78, 53-55. [CrossRef] [PubMed]

52. Meng, E.; Tang, B.; Hou, Y.; Chen, X.; Chen, J.; Yu, X.Q. Altered immune function of Octodonta nipae (Maulik) to its pupal endoparasitoid, Tetrastichus brontispae Ferrière. Comp. Biochem. Physiol. Part B Biochem. Mol. Biol. 2016, 198, 100-109. [CrossRef] [PubMed]

53. Hillyer, J.F.; Strand, M.R. Mosquito hemocyte-mediated immune responses. Curr. Opin. Insect Sci. 2014, 3, 14-21. [CrossRef]

54. Kim, S.G.; Jo, Y.H.; Seong, J.H.; Park, K.B.; Noh, M.Y.; Cho, J.H.; Ko, H.J.; Kim, C.E.; Tindwa, H.; Patnaik, B.B.; et al. TmSR-C, scavenger receptor class $\mathrm{C}$, plays a pivotal role in antifungal and antibacterial immunity in the coleopteran insect Tenebrio Molitor. Insect Biochem. Mol. Biol. 2017, 89, 31-42. [CrossRef]

55. Brehélin, M.; Zachary, D. Insect haemocytes: A new classification to rule out the controversy. In Immunity in Invertebrates; Springer: Berlin, Germany, 1986; pp. 36-48.

56. Ribeiro, C.; Brehélin, M. Insect haemocytes: What type of cell is that? J. Insect Physiol. 2006, 52, 417-429. [CrossRef]

57. Manfredini, F.; Dallai, R.; Ottaviani, E. Circulating hemocytes from larvae of the paper wasp Polistes dominulus (Hymenoptera, Vespidae). Tissue Cell 2008, 40, 103-112. [CrossRef] [PubMed]

58. King, J.G.; Hillyer, J.F. Spatial and temporal in vivo analysis of circulating and sessile immune cells in mosquitoes: Hemocyte mitosis following infection. BMC Biol. 2013, 11, 55. [CrossRef]

59. Gupta, A.P.; Sutherland, D.J. In vitro transformations of the insect plasmatocyte in some insects. J. Insect Physiol. 1966, 12, 1369-1375. [CrossRef] 
60. Csordás, G.; Gábor, E.; Honti, V. There and back again: The mechanisms of differentiation and transdifferentiation in Drosophila blood cells. Dev. Biol. 2021, 469, 135-143. [CrossRef]

61. Yamashita, M.; Iwabuchi, K. Bombyx mori prohemocyte division and differentiation in individual microcultures. J. Insect Physiol. 2001, 47, 325-331. [CrossRef]

62. Berger, J. Nucleolar size in lymphocytes and haemocytes of different species. Eur. J. Histochem. 2008, 52, 149-152. [CrossRef]

63. Berger, J.; Horackova, J. Nucleolar activity of haemocytes in the adult firebug as an alternative animal model. Comp. Clin. Path. 2014, 23, 619-623. [CrossRef]

64. Schuck, S. Microautophagy—Distinct molecular mechanisms handle cargoes of many sizes. J. Cell Sci. 2020, 133. [CrossRef]

65. Malagoli, D.; Abdalla, F.C.; Cao, Y.; Feng, Q.; Fujisaki, K.; Gregorc, A.; Matsuo, T.; Nezis, I.P.; Papassideri, I.S.; Sass, M. Autophagy and its physiological relevance in arthropods: Current knowledge and perspectives. Autophagy 2010, 6, 575-588. [CrossRef]

66. Tattikota, S.G.; Hu, Y.; Liu, Y.; Cho, B.; Barrera, V.; Steinbaugh, M.; Yoon, S.H.; Comjean, A.; Li, F.; Dervis, F.; et al. A single-cell survey of Drosophila blood. bioRxiv 2019, 9, e54818.

67. Severo, M.S.; Landry, J.J.M.; Lindquist, R.L.; Goosmann, C.; Brinkmann, V.; Collier, P.; Hauser, A.E.; Benes, V.; Henriksson, J.; Teichmann, S.A.; et al. Unbiased classification of mosquito blood cells by single-cell genomics and high-content imaging. bioRxiv 2017, 115, E7568-E7577. [CrossRef]

68. Dolezal, T.; Krejcova, G.; Bajgar, A.; Nedbalova, P.; Strasser, P. Molecular regulations of metabolism during immune response in insects. Insect Biochem. Mol. Biol. 2019, 109, 31-42. [CrossRef]

69. Kotoulas, O.B.; Kalamidas, S.A.; Kondomerkos, D.J. Glycogen autophagy in glucose homeostasis. Pathol. Res. Pract. 2006, 202, 631-638. [CrossRef] [PubMed]

70. Zhang, D.W.; Xiao, Z.J.; Zeng, B.P.; Li, K.; Tang, Y.L. Insect Behavior and Physiological Adaptation Mechanisms under Starvation Stress. Front. Physiol. 2019, 10, 163. [CrossRef] [PubMed]

71. Schmid-Hempel, P. Variation in immune defence as a question of evolutionary ecology. Proc. R. Soc. Lond. B Biol. Sci. 2003, 270, 357-366. [CrossRef]

72. Nunes, C.; Sucena, É.; Koyama, T. Endocrine regulation of immunity in insects. FEBS J. 2020. [CrossRef] [PubMed]

73. Urbanski, A.; Rosinski, G. Role of Neuropeptides in the Regulation of the Insect Immune System-Current Knowledge and Perspectives. Curr. Protein Pept. Sci. 2018, 19, 1201-1213. [CrossRef]

74. Toprak, U.; Hegedus, D.; Doğan, C.; Güney, G. A journey into the world of insect lipid metabolism. Arch. Insect Biochem. Physiol. 2020, 104, e21682. [CrossRef]

75. Raposo, G.; Stoorvogel, W. Extracellular vesicles: Exosomes, microvesicles, and friends. J. Cell Biol. 2013, 200, 373-383. [CrossRef] [PubMed]

76. Andrulis, E.D.; Werner, J.; Nazarian, A.; Erdjument-Bromage, H.; Tempst, P.; Lis, J.T. The RNA processing exosome is linked to elongating RNA polymerase II in Drosophila. Nature 2002, 420, 837-841. [CrossRef] [PubMed]

77. Corrigan, L.; Redhai, S.; Leiblich, A.; Fan, S.J.; Perera, S.M.W.; Patel, R.; Gandy, C.; Mark Wainwright, S.; Morris, J.F.; Hamdy, F.; et al. BMP-regulated exosomes from Drosophila male reproductive glands reprogram female behavior. J. Cell Biol. 2014, 206, 671-688. [CrossRef]

78. Korkut, C.; Li, Y.; Koles, K.; Brewer, C.; Ashley, J.; Yoshihara, M.; Budnik, V. Regulation of Postsynaptic Retrograde Signaling by Presynaptic Exosome Release. Neuron 2013, 77, 1039-1046. [CrossRef] [PubMed]

79. Satoh, A.K.; O'Tousa, J.E.; Ozaki, K.; Ready, D.F. Rab11 mediates post-Golgi trafficking of rhodopsin to the photosensitive apical membrane of Drosophila photoreceptors. Development 2005, 132, 1487-1497. [CrossRef] [PubMed]

80. Koles, K.; Budnik, V. Exosomes go with the Wnt. Cell. Logist. 2012, 2, 169-173. [CrossRef]

81. Giglio, A.; Perrotta, I.D.; Brandmayr, P. Exosomes: Ultrastructural evidence in epithelial cells of Malpighian tubules. Micron 2017, 100, 34-37. [CrossRef]

82. Koppen, T.; Weckmann, A.; Müller, S.; Staubach, S.; Bloch, W.; Dohmen, R.J.; Schwientek, T. Proteomics analyses of microvesicles released by Drosophila Kc167 and S2 cells. Proteomics 2011, 11, 4397-4410. [CrossRef]

83. Kim, H.G.; Kwon, K.; Suh, H.W.; Lee, S.; Park, K.H.; Kwon, O.Y.; Choi, J.Y. Exosome isolation from hemolymph of Korean rhinoceros beetle, Allomyrina dichotoma (Coleoptera: Scarabaeidae). Èntomol. Res. 2015, 45, 339-344. [CrossRef] 